\title{
Tourism Development Strategies on CBT of Pindul Cave, Gunungkidul Regency
}

\author{
Muhammad Raditya Fajar Syuhada ${ }^{1 *}$ and Diah Setyawati Dewanti ${ }^{2}$
}

\section{要}

\section{AFFILIATION:}

1,2 Department of Economics, Faculty of Economics and Business, Universitas Muhammadiyah Yogyakarta, Yogyakarta, Indonesia

\section{*CORRESPONDENCE:}

demand.craft@gmail.com

THIS ARTICLE IS AVALILABLE IN:

http://journal.umy.ac.id/index.php/jerss

DOI: 10.18196/jerss.v4i2.10112

\section{CITATION}

Syuhada, M.R.F. \& Dewanti, D.S (2020). Tourism development strategies on CBT of Pindul Cave, Gunungkidul Regency. Journal of Economics Research and Social Sciences, 4(2), 102-117

\begin{abstract}
The purposes of this research are to determine the strengths, weaknesses, opportunities and threats of Pindul Cave Tourism Object as well as create the best strategies in efforts to developing Pindul Cave Tourism Object to increase community income. This research used a descriptive approach, by collecting data in the form of primary data. The analysis technique used in this research are observation, interviews, Focus Group Discussion and documentation. The subjects on this research are managers of tourism object such as Government Tourism Office, Secretary of District, POKDARWIS of Pindul Cave, and tourism stakeholders, seller of bakso tusuk, parking guards, guide. The analysis tool of this research is SWOT analysis. Based on SWOT analysis identifications of Pindul Cave Tourism Object development strategies the results of data collected are; 1 ) internal factors of Pindul Cave Tourism Object which are strengths and weaknesses that can support and inhibit the development of tourism object. 2) external factors of Pindul Cave Tourism Object which are strengths and weaknesses that can support and inhibit the development of tourism object. 3) the best strategy can be executed by Pindul Cave Tourism Object which is SO strategy (Strengths and Opportunities).

Keywords: Pindul Cave; Development Startegy; Income; SWOT Analysis
\end{abstract}

\section{Introduction}

The tourism sector is a mainstay sector in supporting national development. Because of the tourism sector there can be obtained several benefits, namely increasing foreign exchange, expanding employment and improving the welfare of the community. In line with the stages of national tourism development, the implementation of national tourism development is carried out in a comprehensive, balanced, gradual and sustainable manner (Marpaung, 2002). With this, the tourism development sector will have an impact on the economy of the community around the tourism area.

As we have seen, Indonesia has a diverse potential of tourism objects. Indonesian tourism it needs to be given more attention to be optimized and developed because Indonesia is one of the countries that has considerable tourism potential. To increase the local revenue, each region competes and seeks to explore the potential of their natural resources. This was triggered by the implementation of regional autonomy, which demanded that each region develop regional potential based on the resources possessed by each region. 
The enactment of regional autonomy forces every region to develop and see every potential that exists and how that potential can be optimized.

Indonesia as a developing country also has special attention to the development of the tourism industry and development is expected to spur growth Indonesian economy. Besides being useful to improve employment tourism development also aims to introducing and cultivating the beauty of nature and culture of Indonesia and can further strengthen the brotherhood as well national and international friendship (Yoeti, 1982).

This study uses the IFAS and IFAS methodologies, Analyzing the internal environment (IFAS) to find out various possible strengths and weaknesses. Strategic issues to be monitored must be determined because these problems might affect tourism in the future. Analyzing the external environment (EFAS) to find out various opportunities and threats. Strategic issues to be monitored must be determined because these problems might affect tourism in the future.

With the support of quality human resources, the role of tourism is influential in its development towards the present era. Human resources referred to here are those who are able to provide and manage tourism facilities and infrastructure so that they can be used by visiting tourists. In order to attract tourists to visit tourist objects, facilities and infrastructure need to be developed and meet clean requirements. The tourists who visit can feel comfortable while in a tourist attraction if adequate facilities and infrastructure are provided.

By promoting a number of tour packages, it is one of the ways the government develops cave tourism in its region. The purpose of this promotion is to attract domestic and foreign tourists and introduce regional tourist attractions that are still very rarely exploited, the government also promotes through internet media.

One city that has become a tourist destination is the city of Yogyakarta. Besides being known as a student city, Yogyakarta is also known as a city that has many tourist attractions both natural attractions, beach tourism, cultural tourism, and cave tourism. One of the cave destinations in Yogyakarta is located in Gunungkidul Regency. Gunungkidul Regency is a district in the province of Yogyakarta Special Region with its capital city Wonosari. Gunungkidul Regency consists of 18 sub-districts and 144 villages (Permendagri No. 66 of 2011). This district has an area of 1,431.42 km2. Gunungkidul Regency has a variety of economic potentials ranging from mining, fisheries, agriculture, and livestock, industry, flora and fauna, forests and tourism potential. Most of the agriculture, owned by Gunungkidul Regency is rain-fed dry land ( $\pm 90 \%)$ which depends on the climate cycle, rainfall very determine yields. Gunungkidul Regency also has a large number of caves which are located in almost all regions of Gunungkidul Regency, approximately 24 caves in Gunungkidul Regency. 
Table 1 The number of tourists in Gunungkidul Regency in 2011-2016 (millions)

\begin{tabular}{ccccc|}
\hline No & Year & Foreign & Local & Total \\
\hline 1 & & 1.299 & 615.397 & 616.696 \\
2 & 2011 & 1.800 & 998.587 & 1.000 .387 \\
3 & 2012 & 3.751 & 1.333 .687 & 1.337 .438 \\
4 & 2013 & 3.060 & 1.952 .747 & 1.955 .817 \\
5 & 2014 & 4.125 & 2.638 .634 & 2.642 .759 \\
6 & 2015 & 3.891 & 2.989 .006 & 2.992 .897 \\
\hline
\end{tabular}

Source: Buku Statistik Kepariwisataan Kabupaten Gunungkidul Tahun 2017

From Table 1 describe the development of the number of tourists in Gunungkidul in the past 6 years has increased from year to year. But fluctuations in the number of foreign tourist visits, in 2013 the number of foreign tourists in Gunungkidul Regency was 3,751 while in 2014 it decreased to 3,060 tourists. In 2015 the number of foreign tourists rises again by 4,125 tourists, but in 2016 there was a decline in the number of 3,891.

Gunungkidul has arround 24 cave tourism objects, one of which is the Cave of Pindul Cave is located in Gelaran2, RT.03 / RW.16, Bejiharjo, Karangmojo, Gunungkidul Regency, Special Region of Yogyakarta, Around the cave there are also many tourism supporting facilities such as restaurants and hotels that are good and interesting. there are still many people who do not know about the existence of cave tourism potential in Gunung Kidul which can be maximally developed by the surrounding community and local government because it still has many limitations and obstacles in the management and development of tourism especially.

Table 2 The number of hotel accommodation by District in Gunungkidul Regency in 2015 and 2016 (unit)

\begin{tabular}{|c|c|c|c|c|c|c|c|}
\hline \multirow[t]{2}{*}{ No } & \multirow[t]{2}{*}{ District } & \multicolumn{2}{|c|}{ Hotel } & \multicolumn{2}{|c|}{ Room } & \multicolumn{2}{|c|}{ Bed } \\
\hline & & 2015 & 2016 & 2015 & 2016 & 2015 & 2016 \\
\hline 1 & Panggang & - & - & - & - & - & - \\
\hline 2 & Purwosari & 25 & 35 & 358 & 444 & 477 & 592 \\
\hline 3 & Paliyan & - & - & - & - & - & - \\
\hline 4 & Saptosari & - & - & - & - & - & - \\
\hline 5 & Tepus & 6 & 30 & 44 & 257 & 59 & 343 \\
\hline 6 & Tanjungsari & 9 & 40 & 78 & 143 & 104 & 191 \\
\hline 7 & Rongkop & - & - & - & - & - & - \\
\hline 8 & Girisubo & - & - & - & - & - & - \\
\hline 9 & Semanu & - & - & - & - & - & - \\
\hline 10 & Ponjong & - & - & - & - & - & - \\
\hline 11 & Karangmojo & - & - & - & - & - & - \\
\hline 12 & Wonosari & 11 & 15 & 134 & 192 & 179 & 256 \\
\hline 13 & Playen & 1 & 1 & 5 & 8 & 5 & 11 \\
\hline 14 & Patuk & 1 & 1 & 6 & 9 & 8 & 12 \\
\hline 15 & Gedangsari & - & - & - & - & - & - \\
\hline 16 & Nglipar & - & - & - & - & - & - \\
\hline 17 & Ngawen & - & - & - & - & - & - \\
\hline \multirow[t]{2}{*}{18} & Semin & - & - & - & - & - & - \\
\hline & Jumlah & 53 & 122 & 625 & 1.053 & 832 & 1.404 \\
\hline
\end{tabular}

Source: Buku Statistik Kepariwisataan Kabupaten Gunungkidul Tahun 2017

Table 2 informs that the number of Hotels based on Kecamatan in Gunungkidul Regency in 2015 and 2016 has been very good because it has increased from 2015 to 2016 . 
However, there are many sub-districts in Gunungkidul Regency that do not have hotel/lodging facilities, especially around the pindul cave.

Table 3 The number of restaurants by District in Gunungkidul Regency in 2015 and 2016 (Unit)

\begin{tabular}{|c|c|c|c|}
\hline No & District & 2015 & 2016 \\
\hline 1 & Panggang & - & 2 \\
\hline 2 & Purwosari & - & 7 \\
\hline 3 & Paliyan & - & 2 \\
\hline 4 & Saptosari & - & - \\
\hline 5 & Tepus & 8 & 24 \\
\hline 6 & Tanjungsari & 10 & 31 \\
\hline 7 & Rongkop & - & - \\
\hline 8 & Girisubo & - & 5 \\
\hline 9 & Semanu & - & 9 \\
\hline 10 & Ponjong & - & 12 \\
\hline 11 & Karangmojo & - & 19 \\
\hline 12 & Wonosari & 7 & 33 \\
\hline 13 & Playen & 3 & 16 \\
\hline 14 & Patuk & 2 & 8 \\
\hline 15 & Gedangsari & - & - \\
\hline
\end{tabular}

\section{Literature Review and Hypotheses Development}

Pantin and Francis (2005) compiled the resolution of Tourism-Based Tourism (CBT) as an integration and collaboration between understanding and tools (tools) for economic empowerment of society, through discussion, development and marketing of natural resources and cultural resources. Demartoto and Sugiarti (2009: 19) planning CBT as a development of the community by the community and for the community. While according to the author the concept of developing CBT is development that requires access, participation, control and benefits to the community in economic, social, cultural, political and environmental aspects.

According to the Law of the Republic of Indonesia Number 10 of 2009 concerning tourism, it is stated that tourism is a variety of tourism activities and is supported by various facilities and services provided by the community, businessmen, government and local government. Tourism is a travel activity carried out by all the time from the original place of residence to the destination area with the excuse not to settle or earn a living but only to fulfill curiosity, spend leisure time or holidays and other purposes.

Kodhyat (1998) Tourism is a series of activities carried out by humans both individually and in groups within other countries. These activities use convenience, services and other supporting factors that are carried out by the government and / or the community, in order to realize the desires of tourists. 
Tourism is a journey that people do temporarily, which is held from one place to another leaving its original place, with a plan and with the intention not to try or make a living in the place visited, but solely to enjoy pertamsyaan and recreational activities or to fulfill diverse desires. Richardson and Fluker (2004).

Tourism development is a series of efforts to realize integration in the use of various tourism resources integrating all forms of aspects outside tourism that are directly or indirectly related to the continuity of tourism development (Swarbrooke, 1996).

According to Wulandari (2015), there are several things that determine the development of a tourist attraction including:

\section{Tourist Attractions}

The attractions are the attraction of tourists for vacation. Identified attractions (natural resources, human resources, culture and so on) need to be developed to become a tourist attraction. Without tourist attractions, there are no events, other main parts will not be needed.

2. Promotion and Marketing

Promotion is a plan to introduce tourist attractions offered and how attractions can be visited. For planning, promotion is an important part.

3. Tourism Market (Sending tourist community)

The tourist market is an significant part. Although for planning does not needed a complete and in-depth research, but information about the trend of the doer, eagerness, needs, origin, motivation, and so on and tourists need to be collected from those on holiday.

4. Transportation

The income and eagerness of tourists are with the opinion of transportation suppliers. Transportation has a large impact on the volume and location of tourism development.

\section{Research Method}

\section{SWOT Analysis}

Model analysis, SWOT is based on the logic that can minimize strengths and opportunities, and simultaneously can minimize weaknesses and threats (Delita, Yetti, \& Sidauruk 2017). By knowing internal factors, namely (strengths and weaknesses) can be reduced weaknesses, but at the same time can maximize strength. Likewise, with external factors, namely opportunities and threats, when minimized by threats, it can be enlarged with opportunities (Mulyati, Khairiadi, Yana, \& Zein 2018).

The following is a condition analysis that includes an analysis of the conditions of internal factors and external factors in developing tourism strategies around Pindul Cave: 
Internal Factor Analysis

In Pindul Cave Tourism, of course there are strengths and weaknesses that can support development. This power includes a beautiful cave scenery that other caves do not have and, to Pindul cave also has a cave tubing tour who are inside Cave by using buoys, and Access road to Pindul Cave is easy.

\section{Internal Factor Matrix of Pindul Cave}

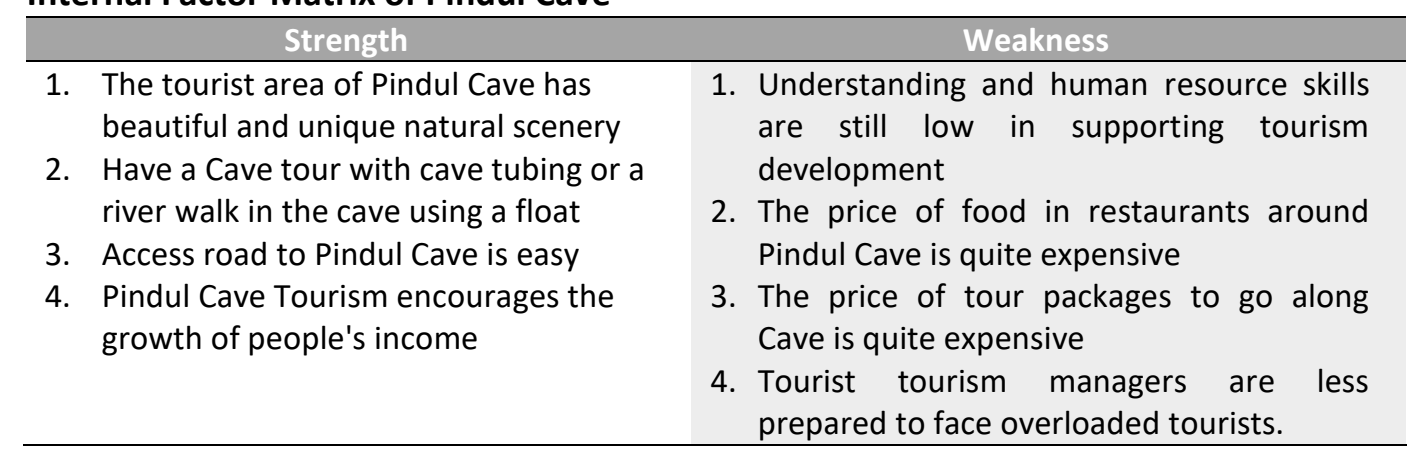

\section{External Factor Analysis}

In developing tourism in Pindul Cave there are various opportunities and threats that can encourage development. Tourism along the Cave along the river flow in the cave makes Pindul's cave famous. After this cave became famous, visitors in Pindul Cave increased because of the many tourists who wanted to visit Pindul Cave. Tourists from Pindul Cave are also aware of maintaining cleanliness and environmental sustainability.

And the image of Gunungkidul tourism area is a competitive, advanced and independent nature and culture, and also the involvement of the community around Pindul Cave in the development of Pindul Cave (Brahmanto, 2013). The threats posed by Cave include natural disasters such as landslides and floods, and during the floods tourists who want to visit Pindul Cave are declining, and this also causes environmental damage, and there is a dispute between the Pindul cave management group.

Table 4 External Factors Matrix of Pindul Cave

\section{Opportunities}

1. The superior image of Gunungkidul tourism area as a nature-based tourist destination is supported by a culture that is sustainable and competitive

2. The high awareness of tourists in preserving the environment

3. The amount of interest of tourists who want to return to Pindul Cave because of the beautiful scenery and adventure tours along the cave with cave tubing

4. Great community involvement in the development of Pindul Cave
1 The occurrence of natural disasters such as landslides and floods

2 There is damage to the environment around the tourist area

3. The decline in visitors after a natural disaster

4. Internal problems between Pokdarwis groups with each other 


\section{Result and Discussion}

To find out how much influence internal and external factors have on the development of Pindul Cave tourism, the researchers used SWOT research. According to (Rangkuti, 2016) SWOT research is very important to do with the aim of analyzing and classifying quantitatively the internal and external factors that affect the organization's business.

The results of SWOT research are numbers. Each question answered by the respondent from internal factors and external factors in the form of a scale will be calculated, so that a certain number is obtained. The scale used is between $1-5$ the values for internal factors (Strengths and Weakness), namely 1 means low and 5 means high. While for external factors (Opportunities and Threats), that is 1 means very high and 5 means low. Because each factor is calculated using numbers, to simplify the calculation process researchers use intervals. The interval determination is as follows:

1. Highest Score $(\mathrm{Xt})$

2. Determining the Range Range

$$
\begin{aligned}
& =5 \text { Lowest Score }(X r)=1 \\
& =X t-X r \\
& =5-1 \\
& R=4 \\
& P=R / X t \\
& =4 / 5 \\
& P=0.80
\end{aligned}
$$

3. Determining Class Length

By using a class length of 0.80 and the lowest score of 1 , the following criteria can be made:

Table 5 Interval Criteria

\begin{tabular}{llll}
\hline No & Interval & S-W & O-T \\
\hline 1 & $1,00-1,80$ & Low & Very high \\
2 & $1,81-2,60$ & Low enough & High \\
3 & $2,61-3,40$ & High enough & High enough \\
4 & $3,41-4,20$ & High & Low enough \\
5 & $4,21-5,00$ & Very high & Low \\
\hline
\end{tabular}

\section{Calculation of Internal Factors}

Based on Table 6, you can find out the following things: Based on Table 6 the average value of strength possessed by Pindul Cave is 4.3 in the very high category. This shows that the strength of the Pindul Cave is very large, so that it can be used in accordance with its development. 
Table 6 Calculation of Internal Factors

\begin{tabular}{|c|c|c|c|c|c|c|c|c|c|}
\hline \multirow[t]{2}{*}{ No } & \multirow[t]{2}{*}{ Internal Factors } & \multicolumn{6}{|c|}{ FGD Respondent } & \multirow[t]{2}{*}{ Average } & \multirow[t]{2}{*}{ Note } \\
\hline & & 1 & 2 & 3 & 4 & 5 & 6 & & \\
\hline & STRENGTH & & & & & & & & \\
\hline 1. & $\begin{array}{l}\text { The tourist area of Pindul Cave has beautiful and } \\
\text { unique natural scenery }\end{array}$ & 5 & 5 & 5 & 5 & 3 & 3 & 4.33 & VH \\
\hline 2. & $\begin{array}{l}\text { Have a Cave tour with cave tubing or a river walk in } \\
\text { the cave using a float }\end{array}$ & 5 & 5 & 4 & 5 & 5 & 4 & 4.67 & $\mathrm{VH}$ \\
\hline 3. & $\begin{array}{l}\text { Road access to tourist attractions Pindul Cave is } \\
\text { easy }\end{array}$ & 5 & 5 & 3 & 5 & 5 & 4 & 4.5 & VH \\
\hline \multirow[t]{3}{*}{4.} & $\begin{array}{l}\text { Pindul Cave tourism encourages the growth of } \\
\text { people's income }\end{array}$ & 5 & 5 & 5 & 5 & 5 & 5 & 5 & $\mathrm{VH}$ \\
\hline & TOTAL AVERAGE STRENGTH & & & & & & & 4.63 & VH \\
\hline & WEAKNESS & & & & & & & & \\
\hline 1. & $\begin{array}{l}\text { Understanding and human resource skills are still } \\
\text { low in supporting tourism development }\end{array}$ & 2 & 4 & 5 & 4 & 3 & 3 & 3.5 & $\mathrm{H}$ \\
\hline 2. & $\begin{array}{l}\text { The price of food in restaurants around Pindul Cave } \\
\text { is quite expensive }\end{array}$ & 2 & 1 & 1 & 1 & 2 & 3 & 1.67 & L \\
\hline 3 & $\begin{array}{l}\text { The price of tour packages to go along Cave is quite } \\
\text { expensive }\end{array}$ & 2 & 2 & 2 & 2 & 2 & 2 & 2 & LE \\
\hline \multirow[t]{2}{*}{4.} & $\begin{array}{l}\text { Tourist tourism managers are less prepared to face } \\
\text { overloaded tourists. }\end{array}$ & 2 & 4 & 5 & 4 & 3 & 4 & 3.67 & $\mathrm{H}$ \\
\hline & TOTAL AVERAGE WEAKNESS & & & & & & & 2.71 & $\mathrm{HE}$ \\
\hline
\end{tabular}

Source: Primary Data Processed, 2019

\section{Calculation of External Factors}

Based on Table 7, in the development of Pindul Cave tourism there are various opportunities factors that can encourage development among them the many interests of tourists who want to return to Pindul Cave because of beautiful scenery and adventure tours along the cave with cave tubing fall into the very high category with an average value average 1.17. This shows that with many tourists who want to visit again, it shows that the Cave of Pindul already has its own attraction so that the managers need to maintain this tourist attraction as well as possible.

Table 7 Calculation of External Factors

\begin{tabular}{|c|c|c|c|c|c|c|c|c|c|}
\hline \multirow[t]{2}{*}{ No } & \multirow[t]{2}{*}{ External Factors } & \multicolumn{6}{|c|}{ FGD Respondent } & \multirow[t]{2}{*}{ Average } & \multirow[t]{2}{*}{ Note } \\
\hline & & 1 & 2 & 3 & 4 & 5 & 6 & & \\
\hline & OPPORTUNITIES & & & & & & & & \\
\hline 1. & $\begin{array}{l}\text { The superior image of Gunungkidul tourism area as a } \\
\text { nature-based tourist destination is supported by a } \\
\text { culture that is sustainable and competitive }\end{array}$ & 1 & 2 & 2 & 2 & 2 & 2 & 1.83 & $\mathrm{H}$ \\
\hline 2. & $\begin{array}{l}\text { The high awareness of tourists in preserving the } \\
\text { environment }\end{array}$ & 1 & 2 & 1 & 5 & 2 & 1 & 2 & $\mathrm{H}$ \\
\hline 3. & $\begin{array}{l}\text { The amount of interest of tourists who want to } \\
\text { return to Pindul Cave because of the beautiful } \\
\text { scenery and adventure tours along the cave with } \\
\text { cave tubing }\end{array}$ & 1 & 1 & 2 & 1 & 1 & 1 & 1.17 & VH \\
\hline \multirow[t]{3}{*}{4.} & $\begin{array}{l}\text { Great community involvement in the development of } \\
\text { Pindul Cave }\end{array}$ & 1 & 1 & 1 & 1 & 2 & 2 & 1.33 & VH \\
\hline & TOTAL AVERAGE OPPORTUNITIES & & & & & & & 1.58 & VH \\
\hline & THREAT & & & & & & & & \\
\hline 1. & $\begin{array}{l}\text { The occurrence of natural disasters such as landslides } \\
\text { and floods }\end{array}$ & 1 & 2 & 3 & 3 & 4 & 5 & 3 & $\mathrm{HE}$ \\
\hline 2. & $\begin{array}{l}\text { There is damage to the environment around the } \\
\text { tourist area }\end{array}$ & 1 & 3 & 4 & 2 & 4 & 4 & 3 & $\mathrm{HE}$ \\
\hline 3. & The decline in visitors after a natural disaster & 1 & 4 & 3 & 5 & 5 & 5 & 3.83 & LE \\
\hline \multirow[t]{2}{*}{4.} & $\begin{array}{l}\text { Internal problems between Pokdarwis groups with } \\
\text { each other }\end{array}$ & 1 & 3 & 4 & 3 & 4 & 4 & 3.17 & $\mathrm{HE}$ \\
\hline & TOTAL AVERAGE THREAT & & & & & & & 3.25 & $\mathrm{HE}$ \\
\hline
\end{tabular}

Source: Primary Data Processed, 2019 
From the Table 7, it can be seen that the results of the acquisition of strength scores are greater than their weaknesses. Likewise, the acquisition of opportunity scores is greater than the threat.

Strengths - Weakness $=2,10-1,20=0,90$

Opportunities - Threats $=2,30-1,50=0,80$

Table 8 Recapitulation of Calculation of IFAS and EFAS

\begin{tabular}{lcc}
\hline No & Description & Total Value \\
\hline 1 & Internal Factor & \\
& Strength & 2,10 \\
& Weakness & 1,20 \\
2 & External Factor & \\
& Opportunity & 2,30 \\
& Threats & 1,50 \\
\hline
\end{tabular}

\section{Factor Internal Strategy Matrix and External Strategy}

Before compiling the SWOT matrix, IFAS (Internal Factor Analysis Summary) and EFAS (External Factor Analysis Summary) were carried out by giving weight and rating to each of the strategic factors.

Table 9 Internal Strategy Factor

\begin{tabular}{|c|c|c|c|}
\hline Internal Strategy Factor & Bobot & $\begin{array}{l}\text { Ratin } \\
\mathrm{g}\end{array}$ & Score \\
\hline \multicolumn{4}{|l|}{ Strength } \\
\hline $\begin{array}{l}\text { a. The tourist area of Pindul Cave has beautiful and unique } \\
\text { natural scenery }\end{array}$ & 0,15 & 4 & 0,60 \\
\hline $\begin{array}{l}\text { b. Have a Cave tour with cave tubing or a river walk in the cave } \\
\text { using a float }\end{array}$ & 0,15 & 4 & 0,60 \\
\hline c. Road access to tourist attractions Pindul Cave is easy & 0,10 & 3 & 0,30 \\
\hline $\begin{array}{l}\text { d. Pindul Cave tourism encourages the growth of people's } \\
\text { income }\end{array}$ & 0,15 & 4 & 0,60 \\
\hline Total & & & 2,10 \\
\hline \multicolumn{4}{|l|}{ Weakness } \\
\hline $\begin{array}{l}\text { a. Understanding and human resource skills are still low in } \\
\text { supporting tourism development }\end{array}$ & 0,15 & 3 & 0,15 \\
\hline $\begin{array}{l}\text { b. The price of food in restaurants around Pindul Cave is quite } \\
\text { expensive }\end{array}$ & 0,05 & 3 & 0,60 \\
\hline $\begin{array}{l}\text { c. The price of tour packages to go along Cave is quite } \\
\text { expensive }\end{array}$ & 0,10 & 3 & 0,15 \\
\hline $\begin{array}{l}\text { d. Tourist tourism managers are less prepared to face } \\
\text { overloaded tourists. }\end{array}$ & 0,15 & 4 & 0,30 \\
\hline Total & 1,0 & & 1,20 \\
\hline Total Overall & & & 3,30 \\
\hline
\end{tabular}

Source: Primary Data Processed, 2019 
Table 10 External Strategy Factor

\begin{tabular}{|c|c|c|c|}
\hline External Strategy Factor & Bobot & Rating & $\begin{array}{l}\text { Scor } \\
\mathrm{e}\end{array}$ \\
\hline \multicolumn{4}{|l|}{ Opportunity } \\
\hline $\begin{array}{l}\text { a. The superior image of Gunungkidul tourism area as a nature- } \\
\text { based tourist destination is supported by a culture that is } \\
\text { sustainable and competitive }\end{array}$ & 0,15 & 4 & 0,60 \\
\hline b. The high awareness of tourists in preserving the environment & 0,15 & 4 & 0,60 \\
\hline $\begin{array}{l}\text { c. The amount of interest of tourists who want to return to Pindul } \\
\text { Cave because of the beautiful scenery and adventure tours } \\
\text { along the cave with cave tubing }\end{array}$ & 0,10 & 3 & 0,30 \\
\hline d. Great community involvement in the development of Pindul Cave & 0,20 & 4 & 0,80 \\
\hline Total & & & 2,30 \\
\hline \multicolumn{4}{|l|}{ Threat } \\
\hline a. The occurrence of natural disasters such as landslides and floods & 0,10 & 4 & 0,40 \\
\hline b. There is damage to the environment around the tourist area & 0,05 & 3 & 0,15 \\
\hline c. The decline in visitors after a natural disaster & 0,05 & 3 & 0,15 \\
\hline d. Internal problems between Pokdarwis groups with each other & 0,20 & 4 & 0,80 \\
\hline Total & & & 1,50 \\
\hline Total Overall & 1,00 & & 3,80 \\
\hline
\end{tabular}

Source: Primary Data Processed, 2019

Based on Table 10, the total score produced by the opportunity factor is 2,30 and the threat factor is 1,50 . So that the total score of the overall factor analysis of the external strategy of Pindul Cave is 3,80.

Based on the results of the weighting and rating carried out through IFAS and EFAS SWOT analysis, the final value of strengths, weaknesses, opportunities and threats can be obtained as follows Table 11 .

Table 11 Recapitulation of Calculation of IFAS and EFAS

\begin{tabular}{lcc}
\hline No & Description & Total Value \\
\hline 1 & Internal Factor & \\
& Strength & 2,10 \\
& Weakness & 1,20 \\
2 & External Factor & \\
& Opportunity & 2,30 \\
& Threats & 1,50 \\
\hline
\end{tabular}

From the Table 11, it can be seen that the results of the acquisition of strength scores are greater than their weaknesses. Likewise, the acquisition of opportunity scores is greater than the threat.

Strengths - Weakness $=2,10-1,20=0,90$

Opportunities - Threats $=2,30-1,50=0,80$

\section{SWOT Analysis}

The results of testing using the IE Matrix are as follows: 
The Internal Overall Score of IFAS $=3.30$ the External Overall Score of EFAS $=3.80$

Total score of Internal and External strategy Factor

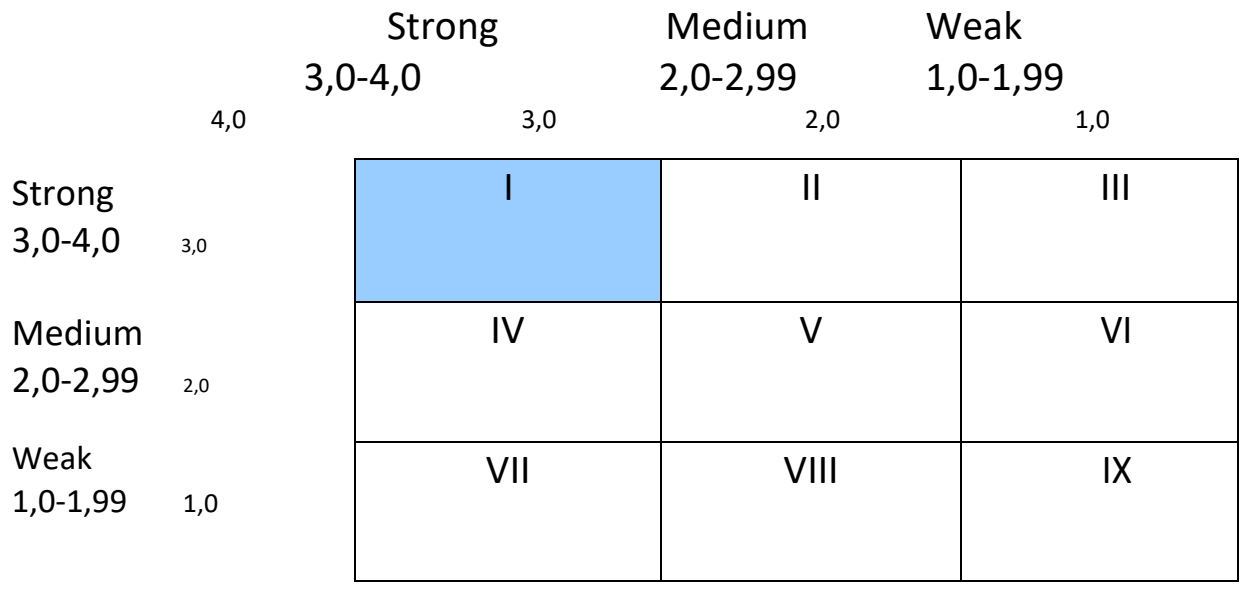

From the results of testing the IE Matrix, it can be seen that the position of the development of Pindul Cave is in quadrant I with a number of internal and external weighting scores of 3,30 and 3,80 respectively. This situation means that Pindul Cave is in Growth position or is developing. The development strategy that can be applied in this strategy includes the development of Pindul Cave's cave tubing tourism and maintaining the Cave area as a clean tourist area of the Cave.

The following is a table that shows the tourism development strategies of Pindul Cave. The strategy is analyzed by the SWOT Matrix. The SWOT matrix is a matrix that can describe how (external) opportunities and threats faced can be adjusted to existing strengths and weaknesses (Zhang, 2018) (internal) as can be seen in the following Table 12.

Based on previous research, research conducted by Pramono and Dwimawanti (2017) about the strategy for developing coastal tourism in Gunungkidul Regency is listed in chapter 2 that the results of the SO, WO, ST, and WT strategy formulation state the strategy. the same thing with the strategy concluded by the researchers. In the results of research conducted by Pramono and Dwimawanti to formulate SO strategies, improve the quality of facilities and beach tourism infrastructure to increase the length of stay of tourists, this was also stated by researchers in its SO strategy, namely, Improving the quality of facilities and infrastructure in terms of comfort and safety of the tourist environment to increase tourist visits. Likewise with the results of the WO strategy formulated by researchers, namely guiding people to become communities that are able to compete, move forward and be independent to support Gunungkidul as nature-based tourism supported by sustainable and competitive culture was also stated by previous researchers. 
Syuhada \& Dewanti

Tourism Development Strategies on CBT of Pindul Cave, Gunungkidul Regency

Table 12 SWOT Matrix

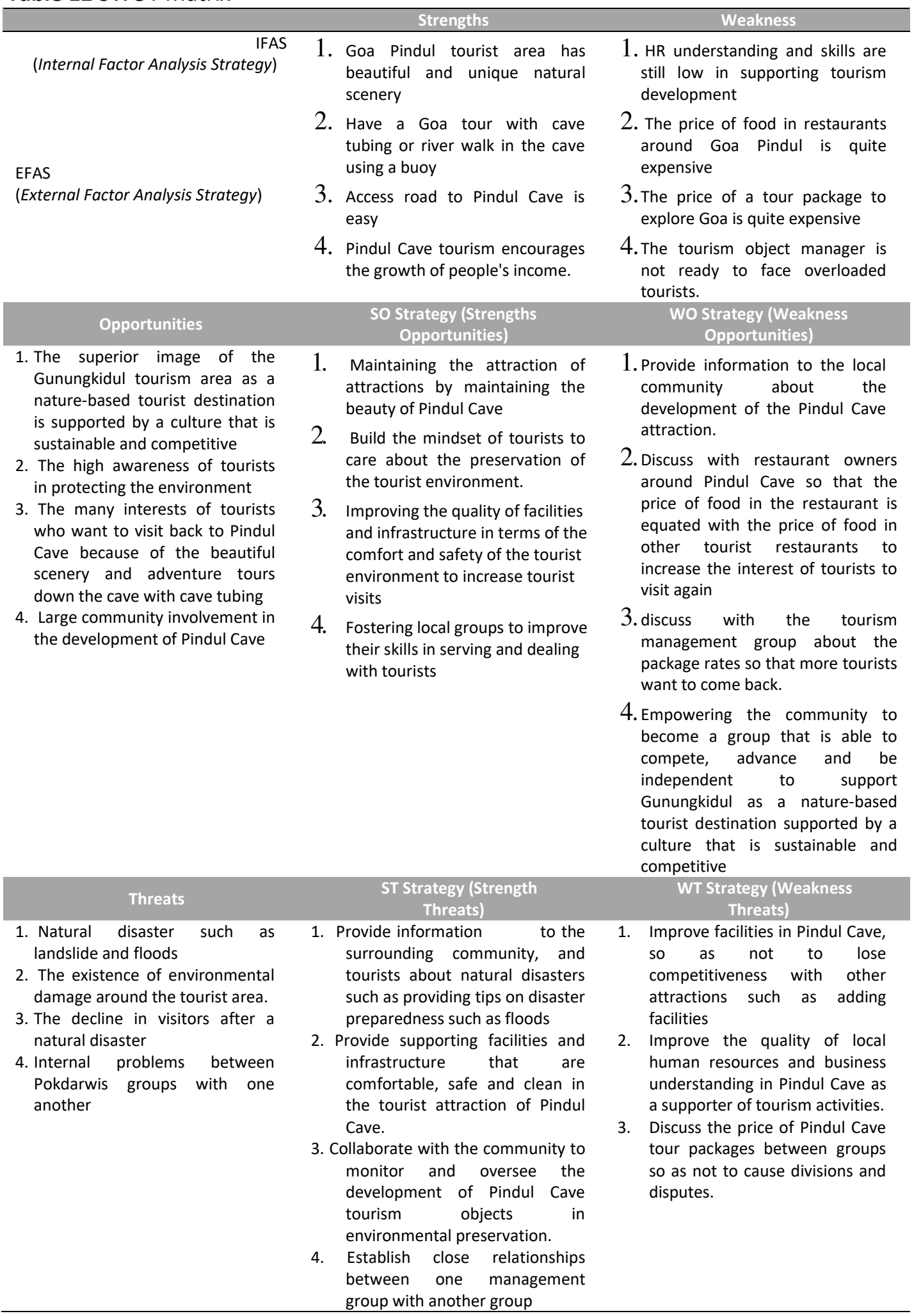


The results of the ST strategy in previous studies were to increase public awareness to manage the cleanliness of beach tourism objects, this was also stated by researchers in the ST strategy, namely Working closely with the community to monitor and oversee the development of Pindul Cave attractions in environmental preservation so that the tourism environment remains awake. And also for the WT strategy proposed by the previous researchers, namely conducting tourism work training, this was also stated by researchers in the WT strategy, namely Improving the quality of local human resources and understanding of business in Pindul Cave as a supporter of tourism activities.

From the results of discussions between researchers and businesspeople, some of whom were members of the POKDARWIS, the researchers received a statement that there was a lack of a good cooperative relationship between the tour operators of Gua Pindul and the local government. Marketing Gua Pindul (2019) said that:

"As far as I know the Government does not have assets here, because the Pindul Cave land is indeed private land and currently the Pindul Cave is also under the auspices of the BUMDes (Village-Owned Enterprises). The government is currently helping such as facilities and infrastructure for direction. Lack of government support especially the tourism office for the development of this Cave made many people develop this tourism object themselves, at first there was a land dispute, but the community supports the development of this Pindul Cave.

Because it is very influential on the economy of the community around Pindul Cave, and the use of Pindul Cave land is also not for personal gain, so all the people here can feel the positive impact of developing Pindul Cave, for example many surrounding communities build public toilets in front of his house for business they and also this also improved facilities in Pindul Cave too". (Marketing Pindul Cave, 42 years old, 2 July 2019).

\section{Conclusion}

Based on the results of the analysis in the previous chapter, the researcher can conclude the efforts to develop the Pindul Cave Tourism Object as follows: Pindul Cave's tourist attraction is the Pindul Cave tourist area which has beautiful and unique natural scenery because Pindul Cave is famous for its beautiful rocks. So, the access road to Pindul Cave is very easy and can be passed by big cars like buses and trucks. Pindul Cave also has Cave Tubing tours or river along the bottom of the Cave using buoys to see the beauty of the rocks in the Cave. And Pindul Cave encourages the growth of people's income.

Weaknesses of Pindul Cave according to observations and interviews at the tourism office that there is a lack of human resources, except for cave walkers because each cave guide does have a special certification, in addition to cave walkers, there are some that can be considered human resources there are inadequate. Then from the results of the interview again the author received a statement about the unpreparedness of the 
tour manager when facing overloaded tourists. And the price of Pindul Cave tour packages is quite expensive at certain tourism agents.

The opportunity for Pindul Cave is that there are many tourists who want to visit Pindul Cave because the Cave tubing experience is rarely found in other tourist attractions. Tourists of Pindul Cave are aware of environmental sustainability and cleanliness so that these tourists do not dare to damage the environment and garbage in this Cave area. The superior image of Gunungkidul tourism area as a nature-based tourist destination that is supported by a sustainable and competitive culture makes Pindul Cave must increase its development as one of the tourist areas in Gunungkidul, with its uniqueness and beauty that will make foreign and domestic tourists want to return to Pindul Cave, and involve the community in the development of this tour.

The threat posed by Pindul Cave is when the flood in the river that flows along Pindul Cave so that after the disaster there was a decrease in visitors and even the temporary closure of the Pindul Cave tourist area, and based on tourism agency interviews there was a dispute between the tour management group and others which resulted in a close relationship out of harmony and the price of the entrance ticket cave between groups.

From the results of the SWOT analysis the best strategy used in the business development of the Pindul Cave tourist attraction is the SO (Strength and Opportunities) strategy or a strategy that utilizes strength to seize opportunities. The strategy is to maintain the attraction of attractions by preserving the beauty of Pindul Cave attractions by protecting tourist areas such as protecting the Cave area yang unik dan beautiful, protecting stalactites and stalagmites which is one of the characteristics of Pindul Cave, Building a mindset to preserve the tourism environment where protecting the natural environment will have a good impact on people's welfare, improve the quality of comfort and safety of the tourism environment to increase the satisfaction of tourists visiting with the beautiful and unique scenery, fostering local communities to improve skills in serving and dealing with tourists by training tour guides to make tourists trained and be sure of their safety, and also increase competence in serving tourists through foreign language training.

From the results of interviews and FGD conducted by researchers, researchers concluded that the development of Pindul Cave uses the principle of CBT (Community Based Tourism) which places the community as the main actor through community empowerment in various activities to develop Pindul Cave. So, the income derived from Pindul Cave tourism is for the community to benefit the surrounding community. Because from the interview, Pindul Cave is on individual land and not government land so that the assets in Pindul Cave are owned by community and village-owned companies as well as investors managed by the surrounding community. when conducting the FGD the researchers accepted the statement that the lack of collaboration between the local government and the community for the development of the Pindul Cave, based on interviews with the tourism office would only regulate the Pindul Cave area so that it is more targeted in the future. because of the many tourist attractions around Pindul Cave 
Based on the conclusions, the researcher gives advice to stakeholders as follows: For the Gunungkidul Regency government, especially the Tourism Office, to contribute more in the development and management of the Pindul Cave tourism area in terms of capital, guidance and marketing. And always work with the local community, especially the Pindul Cave manager and monitor tourism support activities in this Cave.

For the manager of attractions in Pindul Cave, especially POKDARWIS (Tourism Awareness Group) plays an active role in paying attention to the environment around the tourist area, especially concerning the cleanliness of the tourist area. In addition, this further enhances the promotion of Pindul Cave attractions so that more people are known and tourists who visit also increase, and also establish good relationships between groups with each other so as to create a safe and comfortable atmosphere.

For the manager of attractions in Pindul Cave, especially POKDARWIS (Tourism Awareness Group) plays an active role in paying attention to the environment around the tourist area, especially concerning the cleanliness of the tourist area. In addition, this is increasingly increase the promotion of Pindul Cave attractions so that more people are known and tourist visits also increase and more tourists want to return as well, and also establish good relationships between groups with each other so as to create a safe and comfortable atmosphere

\section{References}

Badan Pusat Statistik. (2017). Kabupaten Gunungkidul dalam angka. Hotel dan PARIWISATA, BPS, Kab. Gunungkidul.

Brahmanto, E. (2015). Strategi pengembangan wisata Gua Pindul melalui program pemberdayaan masyarakat sekitar (Studi kasus pada obyek wisata Gua Pindul). Khasanah Ilmu - Jurnal Parinisata dan Budaya, 4(2). https://doi.org/10.31294/khi.v4i2.510

Delita, F., Yetti, E., \& Sidauruk, T. (2017). Analisis swot untuk strategi pengembangan obyek wisata pemandian mual mata kecamatan Pematang Bandar kabupaten Simalungun. Jurnal geografi, 9(1), 41. https://doi.org/10.24114/ig.v9i1.6037

Demartoto, A. (2009). Pembangunan pariwisata berbasis masyarakat. Surakarta: Sebelas Maret University Press.

Kodhyat, H. (1998). Sejarah pariwisata dan perkembangannya di Indonesia. Jakarta: Grasindo. Marpaung, H. 2002. Pengetahuan kepariwisataan. Bandung: Alfabeta.

Mulyati, D., Khairiadi, K., Yana, S., \& Zein, I. (2018). Pengembangan potensi wisata di kota Banda Aceh dengan analisis SWOT. Jurnal Serambi Engineering, 3(1). https://doi.org/10.32672/jse.v3i2.440

Pantin, D. \& Francis, J. (2005). Community based sustainable tourism. UK: UWI-SEDU.

Pramono, A., \& Dwimawanti, I. (2017). Strategi pengembangan obyek wisata pantai di kabupaten Gunungkidul. Journal of Public Policy and Management Review, 6(3), 280-292. https://doi.org/10.14710/ippmr.v6i3.16741

Rangkuti, F. (2016). Teknik membedah kasus bisnis analisis SWOT. Jakarta: PT Gramedia Pustaka Utama.

Richardson, J. I. \& Fluker M. (2004). Understanding and managing tourism. Australia: Person Education Australia, NSW Australia. 
Swarbrooke, (1996). Pengembangan pariwisata. Jakarta: Gramedia Pustaka Utama.

Wulandari, F., Thamrin, I., \& Budiawan, R. (2015). Aplikasi informasi lokasi jalan rusak berbasis web dan android. e-Proceeding of Applied Science, 1(1), 631-635.

Yoeti, O. A. (1982). Pengantar ilmu pariwisata. Bandung: Angkasa.

Zhang, X. (2012). Rural tourism development strategies in Suzhou based on SWOT Analysis. Energy Procedia 16(2012) 1295 - 1299. Retrieved from

https://core.ac.uk/download/pdf/82442963.pdf 